\title{
EXCHANGING ONE UNION FOR ANOTHER? THE FORMATION AND ASCENT OF THE SCOTTISH NATIONAL PARTY
}

\section{Gary CHAMBERS*}

\section{Abstract:}

With increasing frequency, long-established multinational states in Western Europe are fracturing under the centrifugal pressures generated by the desire of ethnonational groups to achieve self-government. In Europe, the EU increasingly serves as a potential ally for ethno-national political movements (perhaps even a potential replacement) to what are perceived as the constrictions of the nation-state. In Britain, the Scottish Nationalist Party (SNP) began to achieve significant electoral competitiveness during the 1960s. It has now reached the point where it was the official opposition in the Scottish Parliament from 1999-2007, then became the largest party in the parliament and formed a minority government following elections on $3^{\text {rd }}$ May 2007. The aim of this article is to survey the genealogy of nationalist mobilisation in Scotland as well as to identify the factors that have fuelled the party's trajectory from that of a fractured pressure group in the 1930s and 1940s to that of a credible political actor today. Importantly, the article will elaborate on the party's oscilating attitudes to European integration since the 1930s and evaluate whether the Party will in fact be able, as it claims, to trade membership of the United Kingdom for membership as an independent state within the EU.

Keywords: Minority Nationalism, Scottish National Party, European Integration, United Kingdom.

*Dr., Marmara University, Atatürk Education Faculty 
özet:

Uzun zamandır hüküm süren çok uluslu devletler, bağımsı etnik-ulusal olma isteğiyle oluşturulan merkezkaç basklsı altında artan bir siklkkla bölünüyor. Avrupa'da AB ulusal devletlerin kisttlamast olarak algılanmasina karşı oluşan etnik-ulusal politik hareketler(belki de potansiyel bir yer değişstirme) için potansiyel bir destekçi görevi görmektedir. Büyük Britanya'da İskoç Ulusal Partisi (SNP) 1960'lt yıllarda seçim rekabetinde önemli başarı kazand. Parti, 1999-2007 ylları arası İskoç Parlamentosu'nda resmi muhalefet partisi noktasına ulaşti, sonrasinda parlamentodaki en büyük parti oldu ve 3 Mayls 2007 seçimlerinde bir azınlık hükümeti kurdu. Bu makalenin amacı İskoçya'daki ulusal birleşmenin kökünü araştırmak ve SNP'nin oluşumunu incelemektir. Bu makale, son zamanlarda Britanyall politikasının ana gündem maddesi olan savas sonraki gündemdeki bölünmüş baskı grubundan olan partinin gelişimini araştırır. Asll olarak, bu makale 1930'lardan beri AT/AB'ye karşı, partinin değişken tavırlarını ayrinttl bir şekilde açıklar ve partinin iddia ettiği gibi gerçekten bağımsız bir $A B$ devleti olabilmek için Birleşik Krallığl üyeliğini devam ettirip ettirmeyeceğini değerlendirir.

Keywords: Azınlık Milliyetçilik, İskoç Ulusal Partisi, Avrupa Entegrasyonu, Birleşik Kralliyet.

\section{Introduction}

Since the 1960s, many multi-national states in western Europe have been confronted both by the desire of ethnonational groups to achieve selfgovernment and the sweeping ambition of European integration. European institutions have gradually precipitated an erosion of the ability of central governments in $\mathrm{EU}$ member states to dominate in many important areas of social, economic and environmental policy. The primacy of nation-states has also been undermined by EU encroachment in some areas of 'high politics', in economic, defence and foreign policy. The forces of minority nationalism across Western Europe and European integration have effectively challenged post-war central government structures in Britain and elsewhere from above and below. 
Similar to many of its European neighbours, the United Kingdom has experienced a revival of ethnonationalism in recent decades. Perhaps indicative of the new political reality in Scotland was the fact that in January 2007, Professor Christopher Smout, the Queen's official historian in Scotland, claimed that Scotland could 'flourish' if it exited the Union. On the eve of the 300th anniversary of the 1707 Anglo-Scottish union in May 2007, a number of opinion polls began to show the Scottish National Party (SNP) to be marginally in the lead on the constituency vote and the second 'list' vote for May 2007's Scottish Parliament elections, suggesting the Nationalists had a genuine opportunity of erasing Labour's electoral primacy in Scotland for the first time. While the SNP was in fact able to emerge as the largest party in the parliament after the 3rd May elections, it was unable to find a coalition partner with which to govern and subsequently formed a minority government.

The SNP leadership has long argued that Scotland would easily be able to exchange its Union with England for a union with Europe. Indeed, since the 1980s, the goals and policy preferences of the Scottish National Party have been increasingly shaped by European developments and the possibilities presented by the option to bypass the nation-state in favour of EU institutions. This article is driven by two key research questions. What have been/are the goals and political strategy of the SNP since its inception? How has the party structured its constitutional preferences in relation to European developments and have these preferences always been consistent? While there is an increasing tendency by nationalist movements to frame their demands in EU terms, is the SNP's goal of 'Independence in Europe' an achievable one as far as the European institutions themselves are concerned? In discussing these questions, it is vitally important to set forth a clear conceptual framework. The first section of this article considers the variagated contours of minority nationalism - its character and demands. The second section attempts to analyse the increasing ways in which member states are subject to supranational strictures of varying intensity from the EU that leave central governments and national political institutions with very few exclusive political and economic competences. The third section will begin by identifying key factors in Scotland's relationship with the Union after the Union was concluded and then proceed to survey the genealogy of nationalist mobilisation in Scotland and account for the formation of the SNP. Section four will identify the party's tortuous path from that of an fractured and irrelevant pressure group to being a 
serious political force that iscurrently the official opposition in the Scottish Parliament. The fifth section will elaborate on the party's oscilating attitudes to European integration since the party's establishment in 1934.

\section{Minority Nationalism}

Invariably, any attempt to analyse minority nationalism needs to take account of the form the classic nation-state has taken. As Montserrat Guiberneau and John Rex have argued (1997:4) '...The nation state was created as a political institution with a territorial base which utilized the doctrine of nationalism in its foundational moment to create a sense of belonging among its members...'. Nationalism, refers as Will Kymlicka (2001:222) has argued, ' '...to those political movements and public policies that attempt to ensure that states are indeed 'nation-states' in which the state and nation coincide...' For the nationalist, the state is a political unit 'belonging' to one ethnic-cultural group which rejects the claims to 'nationhood' made by other people of a different ethnic identity within the state structure. Thus, national identity became a necessary device for ensuring the obedience of the citizen to the state and a device it was hoped that would supersede older, more localised loyalties. Under such circumstances, those who did not identify themselves with the prevailing notion of 'nation' could adopt nationalist ideologies, claim recognition of their own 'nationhood' and struggle for state power.

Importantly, the renewed importance of minority national claims from the 1960s onwards has called into question both the long-term survival of the nation-state and the post-war orthodoxy that modernity would lead to the dilution of ethnic distinctiveness. However, the very concept of minority is a challenging one to define. In many ways, the attempt to offer a viable definition of minority essentially parallels Ernest Gellner's (1983:7) definition of a nation as a group '...that shares some culture or system of ideas, assumptions, behaviour and communication' and whose members 'recognize each other as belonging to the same nation'. Peter Lynch (1996) warns that the very heterogenity of minority nationalism makes it a difficult term to define for two reasons. First, minority nationalism is the product of highly varied historical experiences. Second, the demand for self-determination does not always mean the establishment of a separate nation-state but may consist of a desire to achieve a measure of autonomy. What is clear, as Benedict Anderson (1991:3) has pointed out, is 
that '...the 'end of the era of nationalism,' so long prophesied, is not remotely in sight ...'

Confronted with state nationalism, ethnonationalism ${ }^{1}$ is, as Martijn Roessingh (1997:19) has noted, a 'sentiment that may activate a political movement of an ethnonational group for more autonomy or independence'. For Rudolfo Stavenhagen $(1990: 17)$, ethnonationalist mobilisation '...can no longer be considered some form of archaic, pre-modern, primordial, nonrational form of social action. It is, rather, a legitimate social and political force on a par with, and closely linked to, class and national organisation'. Roessingh (1997:22) has argued that, '... ethnonationalism can be explained as an immediate backlash from unfulfilled promises explicitly or implicitly phrased by the state...Ethnonational communities combine both socioeconomic and cultural-political reasons for political mobilisation against the state'. In other words, it is the failure of state structures that generates a shift in identity and allegiance from membership in a civil state to membership in a ethnic or religious nation. Kymlicka (2001:231) has noted the ways in which national minorities can be systematically disempowered by the state through settlement/migration policies, the undermining of the boundaries and powers of internal political subunits, especially their political and educational institutions and the imposition of a single official language. He argues the '...fact that state nation-building can be minority nation-destroying even when conducted within the constraints of a liberaldemocratic constitution helps to explain why minority nationalism remains a powerful force within Western democracies...'

Ethnonational groups may desire to sever their relationship with one nation-state in favour of a union with their ethnic kin or creation of an independent state. They may also opt for cultural or political autonomy within the existing nation-state, by securing access to resources from the state involving power-sharing, equal opportunities protection and guarantees of civil and political rights, and control over the state in the form of

\footnotetext{
1 Walker Connor used the term 'ethnonationalism' as a clarification of the term nationalism . Ethnonationalism is a form of nationalism where the referent object is the ethnic self-determination of one's own people within a larger state. This is not to be confused with nationalism as a sentiment connected with the 'nationbuilding' policies of a state.
} 
privileged access to state power and protection of economic interests (through preferential treatment, subsidies etc).

National minorities may contain differentiated stances adopted by competing parties, civil society organizations and individual political entrepreneurs. This article will acknowledge the existence of various Scottish nationalisms, which reflects a lack of consensus among Scottish nationalists as to the desired endpoint of their actions. Most significant in this regard is the distinction between what Tom Nairn has called 'Nationalism' with a capital ' $N$ ', those nationalists who want Scotland to assume independent statehood, and small ' $n$ ' nationalists who can setle for differing expressions of autonomythat stop short of independence. In a general sense, these differentiated positions, of course, allow a state to choose whether to address solutions for the nationalist movement overall, a selective part of the movement or for the ethnic group as a whole. In extreme cases, the state may threaten the very existence of minority groups existing in its territory by means of systematic genocide, mass expulsion, forced assimilation, or more rarely by allowing the 'irredentist'minority to secede. In most western democracies, as Kymicka (2001:50) has observed over recent years, '....Rather than pursuing integration, states have accorded national minorities various self-government powers, which enable them to live and work in their own educational, economic, and political institutions, operating in their own language....' In recent years, European states have generally opted for the adoption of some form of power sharing accommodation or autonomy that allows minority groups to obtain some 'ownership' over the decision-making process and recognizes the right to self-realization and internal self-determination

\section{European Integration}

Potentially, the EU represents an attractive option for many minority nationalists. Clearly, membership of the EU offers an alternative institutional framework which can help to lessen the political and economic costs of secession. The EU has gradually acquired for itself the policymaking attributes of a modern state across an increasingly wide range of policy sectors as well as the power to enforce policy decisions. Simon Hix (1999:3) observes that the EU sets over 80 per cent of the rules governing the exchange of goods, services and capital in the member states. Indeed, the EU has achieved a level of legal and material integration far exceeding that obtained by any historical confederation. Jeffrey Anderson (1999:6) has 
noted that few, if any, areas of national policy in the fifteen member states are not in some way- either directly or indirectly-subject to supranational strictures of varying intensity. Thus, the EU cannot be viewed as a traditional regional organization but one in which existing states are being progressively enmeshed into a complex multi-level polity of a new kind (but not necessarily one implying an embryonic Westphalian state). Lynch (1996:14) has argued that '...both minority nationalism and European integration have combined to form a 'pincer' attack on the nation-state, attacking post-war central government structures from above and below, so that central governments have very few exclusive political and economic competences...'

In summary, Keating (2003:2) points to the ways in which European integration has created a legal order and a norm-giving system that allows '...for doctrines of shared sovereignty and constitutional pluralism within and across states...'. Keating (2003) also observes that the loss of nationstate hegemony in functional competences such as market unity and internal and external security has also 'opened up a discursive space for new claims to authority'. Furthermore, European integration supports the claim that democracy can '...function in a pluralistic order beyond the nationstate...' and in a more general sense Europe, and specifically the European Convention for the Protection of Human Rights, undermines '... state claims to be the bearers of universal rights or the only way in which they can be secured...'. In sum, the wider process of European integration has '...encouraged a search for new forms of national autonomy beyond the state and a new accommodation between the principle of nationality and political authority...' In substantive terms, the Maastricht Treaty created a Committee of the Regions composed of 222 representatives of local and regional authorities with the same status as the Economic and Social Committee. ${ }^{2}$ The establishment of the Committee has been seen as a concrete manifestation of the principle of substantive subsidiarity and also

2 Following the May 2004 eastern enlargement of the European Union, the Committee of the Regions was made up of 317 representatives of local and regional government from the 25 member states (24 UK members and 24 alternates). The Scottish Executive's two representatives on the Committee included the First Minister, Jack McConnell. The Committee has rights to be consulted by the Commission and the Council of Ministers, and since the Amsterdam Treaty, the Parliament is obliged to consult 
of the concept of 'partnership', which underlies the operation of the Community's regional policy. The Committee is, however, limited by its purely consultative status, the fact that its membership is decided by national governments. Indeed, the Committee cannot credibly be regarded as a regionally based second chamber of the European Parliament.

Sub-state nations governments and nationalist movements increasingly seek ways to influence EU policies to their advantage, particularly with regard to the use of the European Structural Funds. ${ }^{3}$ Europe has also been perceived as a source of support for minority languages and cultures threatened within large states. Thus, the EU has become a platform in which the sub-state nations personality can be projected and reinforced. The EU has also offered a layer of support for movements concerned with the costs of separating from the nation-state, as in the case of the Scottish National Party and some Basque nationalists. Many functionally-based regions and sub-state nations have opened permanent representative offices in Brussels to lobby Commission officials. Scotland Europa was set up in 1992 to serve as the umbrella organisation promoting Scotland's nongovernmental and commercial interests in Europe. With offices in Glasgow and Brussels, Scotland Europa operates as an alliance of public, private and voluntary bodies who combined to provide a central point of information, analysis and contact for Scotland in Europe. In 1999, the Scottish Executive established Scotland House in Brussels to bring together the Scottish Executive EU Office and Scotland Europa under one roof. Although the various organisations work independently, they work closely together in representing Scotland's interests. These representative offices also allow regional politicians to present themselves as actors in the European arena and to take the maximum political capital for EU initiatives that are beneficial to their individual regions.

Post-devolution, Scotland has made significant efforts to become active internationally. Overall, the Scottish Executive's foreign affairs 'strategy' has been centred on maintaining and developing a network of

${ }^{3}$ From the late 1980 s the Commission has increasingly co-opted allies in the regions themselves in designing programmes and has insisted on partnership arrangements for EU programmes within states. With the fusion of the ERDF, the European Social Fund and the Guidance Section of the European Agricultural Guidance and Guarantee Fund in 1993, regional policy became a vigourous antidisparity policy 
interconnections between Scotland and other territories in the EU that relate primarily to the fertilization of trade links, 'cultural networks' and the exchange of best practice while always emphasizing the primacy of 'relations with the UK'. The Scottish Executive is not intent on formulating an alternative foreign policy to that of London but it is now beginning to develop precise territorial aims in Europe. One recent outcome was the contribution presented by the UK government in the debate on regions and Europe at the European Convention, which was largely authored, by the Scottish and Welsh governments. The question to be asked is the extent to which the EU can realistically serve as a reference point for the ambitions of the Scottish nationalists.

\section{Surveying the Union}

Nationalism was slow to evolve in the Scottish context for one fundamental reason: the usual formulae of building, redeeming or 'imagining' the 'nation' were not valid in Scotland (Nairn, 1997). With the inception of the Anglo-Scottish Union, there was never any danger that Scotland would be subsumed into Britain and become simply a northern appendage to England. The 1707 Union essentially amounted to an amalgamation of Parliaments into a single pan-British legislature in London. The elites of Scottish society continued to hold a near monopoly on law, learning and religious authority following the Union and continued to organize their social and professional lives around Scotland. For Nairn (1997:129), the Scots constituted a nationality which resigned statehood but preserved an enormous amount of the institutional and psychological characteristics normally associated with independence. Unlike Wales and Ireland, Scotland was not subdued by England and remained a self-defining (if passive) 'stateless'nation in the post-Union era. Throughout the nineteenth century, support for the achievements of Britain-its empire, manufacturing, trade and liberties were widely supported by the majority of Scots.

During much of the twentieth century, Scotland appeared to accept the absence of legislative independence in exchange for the tangible politicoeconomic benefits of membership in the United Kingdom. From the late 1960 s onwards a slow consensus appears to have developed in Scotland that the constitutional status quo was no longer acceptable and that British political and economic constructs were increasingly obsolete. The appeal of belonging to Britain declined with the end of the Empire and the decline of 
the UK as a world power. Nationalist and devolutionist programmes only attracted support as deindustrialisation and more particularly, the welfare state, a key source of Scottish loyalty to the Union in the post-war world, appeared to be jeopardized by the neo-liberal radicalism of the Thatcher years. As Stéphane Pacquin (2002:76) has noted, overall Scottish nationalism in the 1980s and 1990s was stimulated by a sense of economic and political betrayal by the British state which had become for many Scots the 'English state', alien and oppressive. For these reasons, Scottish devolution in 1999 became a means of renegotiating the terms of the Union so as to make them more appealing to Scottish public opinion and contain the nationalist pressures embodied by the rise of the SNP.

\section{The Origins of the Scottish National Party}

This section will survey the politicization of modern Scottish nationalism from the formation of the Scottish National Party (SNP) in 1934 to its current position as the official opposition in the (re) established Scottish Parliament. For most of its existence, the SNP was a marginal actor in British and Scottish politics that achieved little in terms of electoral advancement whilst other cross-party organizations such as the Scottish Convention rose to political prominence. In electoral terms, the SNP only began to achieve significant electoral success in the 1960s and mid-1970s when they were represented by 11 Westminster MPs. This was mainly because as Lynch (2003: 2) has pointed out the SNP's electoral fortunes were confronted by the reality that Scottish and British politics were a rigidly two-party affair from 1934 until the mid-1960s. The SNP has been in a position to force the issue of Scottish self-government onto the British political agenda and also to drive the political impetus for the creation of the Scottish Parliament from the 1960s onwards.

The first vehicle of overt political nationalism in Scotland, the Scottish Home Rule Association (SHRA) was set up in May 1886 with the aim of seeking a broad measure of Home Rule that would deal with 'the legislative neglect of Scotland', not dissimilar to that achieved by the post-1999 devolution settlement. The SHRA sought to achieve its goal through generating a cross-party consensus for constitutional change amongst Liberal, Labour and Unionist/ Conservative supporters. It presented the case for a Scottish Parliament as part of a quasi-federal constitutional settlement to the Irish question through Home Rule 'All Round'. As Murray Pittock (2001:101) has commented the SHRA's position '...did not really represent 
a Scottish consensus...'. Politically, the SHRA was most influential in the Liberal Party and after the SHRA's demise, its Liberal members concentrated on presenting Home Rule motions to Parliament. Only one of the bills was successful in passing its second reading in the House of Commons before being abandoned at the outbreak of the First World Warin 1914.As Vernon Bogdanor (1999:120) puts it the frequency of Home Rule bills had less to do with widespread popular support for the idea in contemporary Scotland and they:

... seem rather to have been introduced as ritual gestures on the part of Liberal and Labour MPs who felt duty-bound to argue that Scotland had claims no less important than Ireland...Before 1914, indeed, Scottish nationalism had the character of an imitative and rather artificial movement...

Between 1919-1924 six Home Rule proposals were put before the British Parliament but none were enacted. In the inter-war period the most important nationalist group was the Scots National League (SNL), created in 1920. It was a group founded on the appeal of Celtic revivalism and a pro-Irish stance and as Brown, McCrone and Patterson (1996:137) point out, had distinct 'blood and soil' tendencies. The SNL attempted to draw a racial characterization between Scottish and Irish 'Celts' and (English) Teutons, juxtaposing the democratic and progressive nature of Celts with authoritarian and imperialist impulses of the Anglo-Saxon Teutons. Following a change of leadership in the mid-1920s and the SNL's shift in the direction of party political activity, the Gaelic romantics among the SNL went on to establish the culturalist, Scottish National Movement in 1926, led by the poet Lewis Spence. The importance of the SNL as pointed out by Lynch (2002:33) was that it adopted a decidedly political strategy which focused on party political activity and contesting elections rather than working with other political parties to achieve Scottish self-government (like the SHRA). The SNL was the first of the nationalist organizations to overtly represent itself as an independence party, rather than a Westminsteroriented Home Rule party. Overall, James Mitchell (1996:83) has correctly argued that, '...the SHRA exemplified the weaknesses of the gradualist approach...' and the SNL displayed '...the weaknesses of the fundamentalist approach...'

As Peter Lynch (2002:33) has observed, there were various attempts in the 1920 s to position the issue of Scottish Home Rule onto the political 
agenda, though each met with limited success. When Labour came to power in 1923 as part of a minority administartion, it opted to deal with centralist UK concerns like rising unemployment rather than legislating for Scottish Home Rule. As Pittock observed (2001:105) '...the Scottish Labour team sent off south so hopefully in 1923 were rapidly sumerged in British politics...' In 1928, the center-left pro-independence National Party of Scotland, was established following discussions between the Scottish National Movement, the Scots National League, Glasgow University Scottish Nationalist Association and members of the SHRA. The Party sought as Pittock (2003:270) has argued to '...distance itself from Celtic cultural enthusiasts and those who looked to the Irish example in favour of a more managerial, bread and butter local politics...' The development of the NPS was, however, impeded by the formation of the right-wing Scottish Party which managed to combine a disdain for Pan-Celtic nationalism and socialism in favour of a diluted version of Home Rule which supported Scotland's position within the UK and the British Empire.

\subsection{The Formation of the Scottish National Party}

The existence of two competing nationalist parties represented a major obstruction to the electoral success of nationalist politics as a whole. If the Nationalist movement was to make any political headway, they would have to merge. The Scottish National Party was officially born on $7^{\text {th }}$ April 1934 and since this date, it has existed as the primary vehicle of nationalist organization in Scotland. ${ }^{4}$ However, the merger itself had been forged on one major compromise whereby the NPS clearly abandoned separatism in favour of Home Rule and co-governance of international issues with England. As Pittock (2003: 271) has argued:

...The new SNP was dominated by instrumental nationalists, who saw self-government as a means of improving conditions in the Scottish economy and society hit by the Depression...Cultural nationalists, who aimed at a rebirth of the sense of Scottish nationhood, were often treated with suspicion...

\footnotetext{
${ }^{4}$ Plaid Cymru has been the sole political vehicle of Welsh nationalism since its formation from an amalgamation of existing organizations in 1925. Initially the Party called for dominion status for Wales within the Empire, action to defend and promote Welsh language and culture, and Welsh membership of the League of Nations. Between 1925 and 1945 the Party was incapable of fighting parliamentary seats and the party had minimal impact in electoral terms.
} 
For this reason, Richard Finlay (1993:154) has commented that '...it has to be said that in terms of fighting for "national independence" in the normal sense of the word, the creation of the SNP was undoubtedly a regressive step...'. The Party's growth was also marked by confusion and factionalism within the SNP itself on the shape of any future scheme of selfgovernment. There was to be considerable confict between partisans of a gradualist approach to Home Rule, others who supported a federal constitution for the UK, those who favoured complete independence from the UK and those who proposed dominion status for Scotland within the British Empire. Whereas today's SNP is social democratic and proindependence, the SNP of 1934 was decidely non-ideological, vague in its attitude to Scottish self-government and with few concrete policies according to Finlay (1993:163). Nationalism was also far from being an attractive political option in Scotland during the 1930s not least because of its negative political associations with the blood-and-soil nationalism of Hitler and Mussolini. As Finlay makes clear (1995:79), '... all in all, the nationalists lacked the necessary coherence to operate as an 'effective political party' in the 1930s...'

Although the SNP achieved transitory success in numerous by-elections during the Second World War, ${ }^{5}$ the SNP contested only eight Parliamentary seats in Scotland and won a mere 30,000 votes in the UK general election of June 1945. At this point, the SNP, as Magnus Magnusson puts it (2001:672), ' ...trudged off into the political wilderness as a hard-lineindependence-or-nothing party with a tiny membership...'. In 1942, John MacCormick and other moderaters left the SNP to form the extraparliamentary Scottish Union (later the Scottish Convention) which supported a gradualist approach to Scottish Home Rule. In October 1949, the Convention had launched a petition, a new 'National Covenant', which stated that:

We, the people of Scotland who subscribe this engagement, declare our belief that reform in the constitution of our country is necessary to secure good government in accordance with our Scottish traditions and to promote the spiritual and economic welfare of our nation...We

5 In 1944 an SNP candidate received 42 per cent of the vote in a by-election in Kirkcaldy. Robert McIntyre also became the party's first MP, elected in the Motherwell by-election in April 1945 but then lost the seat soon afterwards at the general election in June 1945. 
solemnly pledge ourselves, in all loyalty to the Crown and within the framework of the United Kingdom, to do everything in our power to secure for Scotland a Parliament with adequate legislative authority in Scotland's affairs... (Cited in Magnusson, op. cit., p. 673)

The Covenant attracted two million signatures in the first years of the 1950s; it was, as Magnusson claims, a powerful expression of Scottish middle-ground sentiment for Home Rule rather than independence. Pittock (2003:276) also notes that the Convention was a momentous attempt to demonstrate the wide (if arguably shallow) sympathy for Scottish Home Rule. The post-war activities of the Scottish Convention provided a significant challenge to the electoral viability of the SNP. As a result of internal dissent, weak grassroots organisation and recurrent financial problems, the party was unable to advance electorally during the 1940s and 1950s.

\subsection{The SNP: From Protest Vote to Nationalist Breakthrough}

The development of electoral success for the SNP was a particularly slow process given that it tended to act as a 'protest vote' against the two major parties of Labour and the Conservatives; what Bogdanor has termed (1999:122) a '...temporary departure perhaps from a stable political norm...'. The electoral success of the SNP evident in Scottish local government elections from 1961 to 1966 and the ability to contest more parliamentary seats at the general elections of 1964 and 1966, came as a result of a more coherent approach to policy formulation, improved organizational capacity and stronger finances. The SNP's success at the Hamilton parliamentary by-election and the local council elections of 1967 to 1968 demonstrated that the Party managed to transform itself from an electorally irrelevant pressure group to a mass political party within a relatively short period of time. ${ }^{6}$ As Pittock (2003:278) pointed out, '...The Scottish Nationalists began to gain ground in the face of dissatisfaction with Labour's failure in government to arrest Scottish decline and (probably) as a result of the final collapse of the British Empire, which removed the international dimension from Britishness...'. The 1970 general election saw

\footnotetext{
${ }^{6}$ Plaid Cymru's electoral support also increased during the 1960 s. The party won its first parliamentary seat at a by-election in 1966 and gained $11.5 \%$ of the Welsh vote in 1970. The party also elected three members of parliament at the October 1974 general election.
} 
the SNP win its first seat at a general election. The party's overall 11.4 per cent of the Scottish vote provided the party with a strong base that allowed it to achieve a breakthrough at the general elections of 1974. In the general election of February 1974 the SNP gained 21.9 per cent of the Scottish vote and seven MPs. In the October 1974 election the SNP won 30.4 per cent of the vote and elected 11 MPs. These results not only put the SNP on the political map, but also ensured that the issue of Scottish self-government was taken seriously. As Bogdanor (1999: 123-4) has pointed out, it seemed as if '.. what might perhaps originally have been a protest vote appeared to be solidifying into something much deeper. It seemed that a new alignment was developing in Scottish politics...' Indeed, the SNP attracted support from across all social classes in 1974.

The discovery of North Sea Oil in the early 1970s was shrewdly manipulated by the SNP into the potent slogan, 'It's Scotland's Oil' and opened up the possibility of an alternative Scottish future- a Scotland that could more than pay her way in the world and develop into a prosperous, self-confident, independent nation.

As James Mitchell observes it is also important to recall that the winter of 1973-4 was a time when external events exacerbated difficulties at home. As Mitchell (1996a:96-7) has observed, war in the Middle East and the ensuing energy crisis combined with industrial relations problems at home to create an image of Britain as a country in deep trouble. Despite the fact that Unionism was apparently in terminal decline, it would clearly be an immense challenge for the SNP to achieve independence by attempting to win the majority of the Scottish seats in the British Parliament, and on that basis claim a popular mandate for negotiating Scotland's independence from the UK. When Harold Wilson became prime minister of a minority government in 1974 he urgently required the votes of the Scottish and Welsh nationalist MPs to ensure the survival of his administration. The government predictably reversed its previous opposition and came out in support of devolution in 1975, advocating a directly elected assembly for Scotland with legislative powers. The government foresaw, however, no devolution of revenue-raising powers and the Cabinet office of Secretary of State for Scotland would remain. The government would not devolve major economic and industrial powers or matters related to agriculture or energy. (The scheme of devolution proposed by the bill was complicated by the inclusion of the Cunningham amendment which required forty per cent of 
the registered electorate plus a majority of voters to support devolution in a referendum if it were to be subsequently implemented).

The referendum on Scottish devolution was held on 1 March 1979 and produced a narrow 'Yes' vote of $51.6 \%$ while 48.4 per cent voted 'No'. It is worth noting that the No campaign, unlike the Yes campaign, was very well funded. The referendum, however, fell on the basis of the 40 per cent rule. The Callaghan government had mistakenly held the devolution referendums during the industrial and economic troubles of the 'Winter of Discontent' of 1978-9 when the popularity of the Labour government was at a very low point. As Mitchell (1996a: 97) observed,

...the measure was seen as inadequate and its association with a failing government did not help...a measure designed principally to appease Scottish nationalist sentiment had become associated with the poor economic performance of a British government ...Scottish Home Rule was thwarted because it was not seen as an alternative to British decline but was associated with it...

In 1979, Labour's devolutionary Scotland Bill was narrowly accepted in a referendum but not implemented by the Conservative government that was subsequently elected. As Lindsay Paterson (1994:169) points out the weakness of the support for Labour's devolutionary scheme, '...can best be interpreted as a continuing preference by the Scottish electorate for the type of technocratic autonomy that had worked fairly well between 1945 and the late 1960s: even a limited Parliament was believed to put these gains at work...'. Given the limited powers of the proposed non-legislative and nontax raising assembly, many in Scotland were right to be doubtful of its potential usefulness.

The 1970s were a turbulent period for the SNP as it shifted from electoral success to decline brought about by splits in organisational and decision-making structures and confusion about the Party's ideological identity (were they social democrats or 'Tartan Tories' as Labour claimed?) as well as the Party's stance over the detail of devolution. As Peter Lynch (2002:176) has observed in the post-1979 period intra-party splits were at their most intense, with conflicts over both ideology and party strategy. The 79 Group which was already in formation within the party at the time of the referendum and general election in 1979 dedicated itself to the principles of independence, a socialist redistribution of power, income and wealth and the establishment of a Socialist Republic of which only the first of these 
principles was SNP policy. In 1982, the party's national executive declared that those involved in the 79 Group were members of an organization incompatible with membership of the SNP and expelled most of its key members. The 79 Group was not the only internal faction in the early 1980 s SNP. At the same time as the 79 Group surfaced, an extreme group of Celtic romanticists emerged-Sion Nan Gaidheal (SNG). This group, unlike the $79 \mathrm{ers}$ had no policy aims for the SNP and favoured direct action tactics. Concerned at the potential for SNG to seriously damage the SNP through associating it with extremism, the party leadership proscribed the organization in 1981.

\subsection{The revival of the SNP}

It was arguably only in the 1990s with the election of Alex Salmond as party leader that the SNP was able to re-emerge as a credible force. In the 1990 s, the SNP also committed itself to more participatory politics with the involvement of civic Scotland in policy discussions. As Lynch (2002:228) has pointed out, these consultative assemblies were accompanied by a large number of bilateral meetings between SNP spokespersons and leading pressure groups in Scotland.

The SNP has also attempted to characterize Labour as a 'Thatcherite' party since the right-ward shift of the Labour Party under Tony Blair. The Scottish Election Surveys of 1997 and 1999 found that between the UK and Scottish elections of those years, the proportion of people in Scotland believing that New Labour acted in the interests of the working class had fallen from $90 \%$ to $51 \%$ and the number believing that the Labour Party acted in Scotland's interests had fallen from $68 \%$ to $40 \%$. The SNP has successfully 'branded' itself as a social democratic party in the European mainstream and its effort to attract support from disillusioned Labour voters is one that continues apace. As one SNP media officer, Joe Middleton (2001), described it: ' ... New Labour no longer represents our forefathers instead it represents a watered down form of Thatcherism disguised by muddled middle class values, the terrible exploitation of the poor and weak in our society began by Thatcher and continued by Major will not be stopped by Labour...'.

Given the popularity of devolution within Scotland, the SNP had little choice other than to support the referendum campaign of 1997. In the formal launch of the 'Yes, Yes' campaign on 22 August 1997 Salmond 
stated: '...We believe that devolution is not an end, but a beginning-a step towards real Independence. We hope to persuade the people of Scotland to share that view and to act on it. But to commence on any journey, we must take our future into our own hands...' (cited in Lynch, 2002:223). Or as Scottish secretary, Dr. John Reid, commented of the SNP position in 1999: '...They support the Scottish Parliament the way a rope supports a hanging man. They support devolution in order to strangle a devolved settlement because they recognise devolution means a Scottish Parliament within the United Kingdom...' ('UK:Scotland Reid accused',1999)

The SNP's manifesto at the 1999 election was specifically designed to attract traditional Labour voters through its social democratic policy committments- the manifesto set out proposals for increased public expenditure in health, education and housing which it proposed to finance through an increase in income tax. Furthermore, the SNP's manifesto agreed to support the idea of devolution but only as a stepping stone to complete independence.

In the first Scottish election in 1999, the SNP emerged as the second party in Scotland. The party argued that if it gained a role in the Scottish Executive, it would attempt to hold an independence referendum within the Parliament's four year term. Following the 2003 elections for the Scottish Parliament, the SNP remained the leading opposition party in the Scottish Parliament (albeit with fewer members). In the period prior to the Scottish Parliament elections in May 2007, Mr Salmond repeatedly insisted that the question of a referendum on independence would be non-negotiable if the SNP became the largest party in the Scottish Parliament and the dominant party in a coalition. In March 2007, Mr Salmond served notice that if he became First Minister, he would work for a white paper on an independence referendum within his first 100 days of taking office. The SNP appears to have been successful in converting disenchantment with the Labour government into active support for the SNP. On March 18 th 2007, Salmond declared that:

Tony Blair has taught us the lessons of why we need independence to have responsibility for the big decisions on the economy, for the environment, against war and to stop weapons of mass destruction being deployed in Scotland. Scotland needs real powers. We need independence. (cited in Carrell, March 2007) 
At the same time, it is necessary to point out that public opinion in Scotland is not necessarily as clear cut in its support for the independence option as the SNP might wish. For example, an ICM opinion poll for The Scotsman published on the $16^{\text {th }}$ January 2007 , the 300 th anniversary of the Act of Union's approval by the Scottish Parliament, found that only 32 per cent of Scots agreed that the United Kingdom should break up- with Scotland and Wales each gaining their independence. The same poll found that 42 per cent of the 18-24 age group believed the Union has had a positive impact on Scotland, while only 19 per cent felt it had been negative. As Murray Pittock rightly observes (2001:12) the strength of Britishness as a cultural and social solvent remains seriously underestimated by contemporary nationalist commentators. In this regard, David McCrone (2003) has commented that there are multiple ways of defining Britishness:

...for people living in Scotland, there is a repertoire of ways of being British. For those born and brought up in Scotland, it can mean a synonym for 'English'; simply a fact of bureaucratic life, expressed by having a British passport; evoking a (regrettable) imperialist legacy; evoking the regrettable end of Empire; a statement of political Unionism; a liberal civic identity uniting diverse nations and ethnicities in the same state...

Regardless of the reasons for the SNP's ascent, opinion in Scotland is considerably more divided on the desirability of independence than at first may seem apparent.

\subsection{The SNP and the question of European Integration}

The SNP's embrace of a pro-European dimension has been a long and complex one. While endemic factionalism between fundamentalists and gradualists excluded the possibility of the party actively capitalizing on the European dimension in the 1930s, ${ }^{7}$ the SNP did, however, advance an active commitment in 1935 to Scottish participation in the League of Nations, which would involve '...the Scottish people taking their natural place

\footnotetext{
${ }^{7}$ Plaid Cymru were markedly more enthusiastic about the notion of European union during the 1930s and 1940s. Before the establishment of the European Community in 1957, Plaid Cymru was supportive of European integration. By the end of the 1960s, and similar to the SNP, the party had adopted a hostile approach to the reality of European union. The party opposed UK membership of the EC and was sympathetic to the merits of the European Free Trade Association.
} 
amongst the nations of Europe in the vanguard of peace and progress...'. (cited in Lynch, 1996, p.26)

During the 1940s, the SNP developed a position that linked Scottish selfgovernment and the cause of European integration. As Lynch (1996:27) makes clear:

...As SNP chairman, Young brought the European dimension to the fore...Y Young's efforts brought the SNP from vague support for international co-operation to concrete support for Scottish participation in any new institutions for international and European co-operation that would come about at the end of the Second World warfare..

Pittock (2001:126) has observed that the Party's pro-Europeanism was again in evidence when in 1948, the party voted to '... support European unity...' The SNP's position shifted in the 1970s when the party's narrow emphasis on sovereignty caused the SNP to see European integration and European institutions as centralist and bureaucratic. In the 1970s, the SNP's goal was defined as independence under the British Crown inside the Commonwealth but outside the European Community. At that juncture, the Party saw the process of European economic integration, based on free trade and market liberalization as a process that would have damaging effects at a time when Scotland was undergoing de-industrialisation of traditional heavy industries and the resultant economic, social and political dislocation. The SNP's anti-European position was linked to the fact that the European Commission at the time made no attempt to encourage participation by other players not representing sovereign governments. The majority in the party, therefore, opposed entry into the EC in 1972 and even argued that membership of the EC was in violation of certain sections of the Treaty of Union of 1707. As Lynch (1996:32) puts it, the SNP offered two organizational alternatives to the $\mathrm{EC}$ as its preferred mechanism for international economic and political co-operation: a free trade area organized around the members of the OECD, and the development of a common foreign and defence policy around the existing Council of Europe.

The SNP unanimously campaigned for a No vote when the government held a referendum on continued membership of the EC in $1975 .^{8}$ Public

\footnotetext{
${ }^{8}$ Plaid Cymru's slogan at the referendum was 'Europe Yes, EEC No'. Nevertheless, the Weish voted in favour ('Yes' vote was $64.8 \%$ of the total). By
} 
opinion in Scotland, however, shifted gradually to continued membership of the EC. The Scottish Yes vote represented 58.4 per cent of the vote (the Yes vote was 68.7 per cent in England).Thus, Scotland voted in favour of membership by a significantly smaller margin than was the case in England, and provided the only districts in any part of the UK, which voted No. Scotland was still inward-looking: its nationalists had demarcated their difference from England, but many still regarded the EU as alien. The possibility of electing members of the European Parliament in 1979 directly influenced the SNP's attitude to Europe. The election of their first MEP to the European Parliament in 1979 enabled the SNP to become familiar with the institutions in Brussels and gain a better understanding of EU policies.

\subsection{Independence in Europe}

After the 1983 general election, the SNP leadership sought to shift the SNP onto more moderate political ground over the issues of devolution and Scottish membership of the European Community (Lynch, 2002). In 1983 the SNP conference agreed to support Scottish membership of the European Community and to adopt a more constructive approach to devolution and cross-party co-operation. In its 1984 European elections manifesto the SNP declared that:

Many of the fears that the Common Market would become a new superstate have been eased by experience. Far from becoming a new European despotism where bureaucracy triumphed over national rights, the enlarging of the Community in recent years has diluted some of the dangers of centralism. The bigger it gets, the looser it becomes...(European Election Manifesto, SNP, 1984).

In 1988 the SNP adopted the policy of Independence in Europe and clearly promoted Scottish membership of the EC as an aid to secession. The SNP, as Paolo Dardanelli (2001:7) has pointed out, could '...claim that within an integrating Europe, an independent Scotland would neither be truly separated from the UK nor would it be isolated on the world stage. This opportunity reduced the costs of secession because it made it less traumatic in symbolic terms'. For Pittock (2001:126-7), Scottish nationalism could now be viewed as internationalist, increasingly so as the xenophobia of Conservative Euro-Skepticism became more prominent in England. As

1989, Plaid Cymru had also shifted to support for independence in Europe but independence within a federal and decentralized Europe of the Regions. 
Lynch (2002:187) has pointed out, '... The adoption of independence in Europe was almost overwhelmingly supported by SNP activists and members...'

Importantly, as Lynch (1996: 50) points out, the Europeanization of SNP party goals, demonstrates the acceptance of the limits of independence and the constraints upon nation-states operating in a global economy and international system. The SNP's emerging pro-European position was reflected in the title of the party's 1992 General Election programmeIndependence in Europe: Make It Happen Now-the 1992 Manifesto of the Scottish National Party. Support for the commitment to independence in Europe was articulated by Alex Salmond (1992:3) leader of the SNP, in the following terms:

...Right across Europe, nations are asserting their right to selfdetermination- a fundamental principle enshrined in international law. The newly-liberated nations of Eastern and Central Europe- many of them smaller and all of them poorer than Scotland- are queuing up to join the European Community, alongside many of the former EFTA countries. None of them would settle for some sort of second-rate regional status; all insist on becoming independent member states in their own right...

In 1997, Salmond noted that in an independent Scotland could:

...play our part in the political reform of the Community, arguing for greater democracy and accountability within EC structures to close the "democratic deficit." Our objective is not a European super state but a confederal Community of independent nations which choose to share their sovereignty and cooperate more closely for the benefit of all, while still retaining their rich diversity... (cited in Kikas, 1997)

It's important to note, however, that the SNP has consistently criticized the notion of a 'Europe of the Regions' promoted by devolutionists claiming it would create inferior representation in European institutions rather than national representation on all the bodies of the EC/EU that they seek and would serve only to influence the decision-makers but prevent the regions from becoming decision-makers in their own right. John Swinney (2003:1), then leader of the SNP, speaking to the Scottish Council of the European Movement clearly characterized the position of the SNP both:

....as a pro-Europe and pro-EU party ...At present our status in Europe is not of a full member, but that of a region. And while we 
support moves to involve regional governments more fully in the decision-making processes of the EU, regional status will always be second-best. For Scotland, it means far too often looking across the border, when we should be looking across the world.

For the SNP regional status within the EU is clearly unattractive given that many new accession states are full and equal members of the EU but have smaller populations than Scotland. In the European Parliament elections of June 2004, the SNP made much of the point that if Malta, population 400,000 could secure full membership in the EU, then it was incumbent on Scotland to achieve the same goal. In his speech to the Scottish Council of the European Movement, the SNP leader also observed that the EU has been good for the small, independent nations of Europe and remarked that EU membership had opened up opportunities and provided a platform to promote values and to defend national interests. Swinney (2003:5-6) further commented that the impressive record of the existing small countries of the EU was a powerful signal for what others could achieve and that Scotland could not afford to be left behind. In March 2007 during the campaign for the Scottish parliament elections, the SNP leader Alex Salmond indicated if he became First Minister, he would advocate that Scottish ministers lead UK delegations to the EU council of ministers in areas where the Scottish interest was of primary concern.

\subsection{The Feasibility of an independent Scotland and relations with the EU}

The SNP leader Alex Salmond (2007) has frequently pointed to the ways in which a post-independence Scotland:

...would prosper as a small European nation. As we can see from our near neighbours in the "arc of prosperity" - Ireland to our west, Norway to our east, and Iceland to our north - independence works in the modern world. All of these nations have become independent in the last century - it is the natural state for the most successful nations...

While 'Independence in Europe' has long been an essential component of SNP discourse, in early 2004, the European Commission indicated that an independent Scotland would not automatically become a member of the EU if Scotland were to exit from the United Kingdom. This likelihood was suggested in a written response by the then President of the European Commission, Romano Prodi to a general question from a Welsh Socialist 
MEP about whether a newly -independent region of an existing member state would have to leave the EU and reapply for membership. While referring to no specific countries, Prodi gave his view that '... when a part of the territory of a member state ceases to be a part of that state, e.g., because that territory becomes an independent state, the treaties will no longer apply to that territory. In other words, a newly-independent region would, by the fact of its independence, become a third country with respect to the European Union and the treaties would, from the day of its independence, not apply any more in its territory...'.

EU Commission President Prodi further observed that ' ...this agreement is subject to ratification by all member states and the applicant state...' Both the Labour Party and the Liberal Democrats argued that Prodi's view unambiguously contradicted the SNP argument that Scotland would remain a member state of the EU while there was a process of negotiation in progress for Scotland to secede from the UK and that having to reapply for EU membership would only be a matter for any independent state that was not already a part of the EU. The SNP rejected the position elaborated by the Commission president and argued that the Prodi's statement needed to be interpreted as an intervention in Italian domestic politics. Clearly, Prodi's statement represents a major problem for a party like the SNP which has built its strategy of independence from Westminster on membership of the EU. (cited in Denholm, 2004).

Salmond has subsequently asserted that '....Scotland is already a member of the EU and that would continue. It is not easy to leave the EU as we saw with the attempts by Greenland when they won autonomy from Denmark...' Equally, the European Commission has since reiterated its earlier position. The Commission's representative in Scotland, Neil Mitchison, confirmed in January 2007 that Scotland would not be granted automatic entry into the EU, as the Nationalists claim. '...The situation is unprecedented and therefore negotiations would be needed. Things would have to be discussed and negotiated...' the European Commission's representative said. (cited in The Scotsman $8^{\text {th }}$ January 2007)

Overall, it appears that Scotland would have to negotiate its accession to the EU as a new member state both as a matter of international law and as a matter of EU law. Thus, the question of 'Independence in Europe' appears to be a problematic one as it is arguably based on a number of untested assumptions. Matthew Happold (1999:10) has argued that 
$\ldots$ an analysis of the applicable law and practice is that an independent Scotland's position in Europe cannot be taken for granted. Were Scotland to gain independence, it would be the rump UK, not Scotland, that would inherit membership of the EU. Scotland's subsequent route to EU membership could well be a tortuous one. The SNP's use of the phrase Independence in Europe seeks to persuade the Scottish electorate that it can have its cake and eat it, that Scotland can have both the benefits of independence and the security of membership of the European Union. However, the real situation is that an independent Scotland might end up with all the insecurities of independence and none of the benefits of EU membership...

Happold also warned that an independent Scotland would almost certainly lose its share of the UK budget rebate, that it would lose anything that remains of the EU's structural fund money, that it would lose power and influence and would have to compete with other emerging European states for attention and resources. John Bachtler, Francois Josserand and Rona Mitchie, (2003:10) have noted the fact that a partial or total loss of the Funds would be seriously detrimental to the economic development of Scotland in financial and policy terms.

\section{Conclusion}

In contrast to other European countries, the electoral dominance of the two main parties-the Labour and Conservative Parties- and the nonproportional voting system used at British general elections have provided a permanent obstacle to SNP electoral success. The post-1945 creation of the welfare state, economic centralization and full employment during the 1950s marginalized the SNP which lacked coherent organisational and decision-making structures, suffered from low party membership, factionalism and divided leadership and recurrent financial problems. It was only in the $1960 \mathrm{~s}$ and in a context of rising unemployment, growing disenchantment with the two main parties-Labour and the Conservativesand the visible failings of the centralised UK economy and government that the party's electoral prospects improved dramatically. The decline of the British Empire removed one of the major bulwarks for a British identity in Scotland. From the late 1960s/early 1970s onwards, the SNP was to become a credible political actor in wider British politics capable of actively articulating and promoting the issue of Scottish self-government. The party's electoral successes in the 1970s led its opponents to support of 
devolution and the establishment of a Scottish Parliament. By the late 1980s the SNP began to recover from its post-1979 internal conflicts and effectively positioned itself as a left of centre political party in order to both challenge Labour and more importantly, to generate an anti-Conservative political consensus in Scotland. The adoption of the flagship policy'Independence in Europe'- in 1988 was a means to address antiindependence critiques that secession would represent a risky adventure culminatating in economic dislocation and isolation. The establishment of a Scottish Parliament in 1999 allowed the SNP to campaign to 'complete' the devolution process to deliver independence and offered the party a credible prospect of becoming a party of government at a future Scottish election, a position which it has now achieved. It seems, however, improbable that either devolution (or more accurately, disillusion with devolution) is leading inevitably to ultimate independence from the UK at any point in the near future. It should be stressed that unlike many minority nationalist movements in Western Europe which seek federalist-type innovations within existing states, the Scottish National Party is firmly committed to the cause of unconditional, independent statehood. However, the question of whether Scotland would easily be able to 'exchange' its Union with England for a union with the EU remains very much a contested and uncertain one.

\section{References:}

Anderson, B. (1991). Imagined Communities: Reflections on the Origins and Spread of Nationalism. London: Verso

Anderson, J.J. (1999). Introduction. In J.J.Anderson (Ed.). Regional Integration and Democracy: Expanding on the European Experience (pp.1-21).Oxford:Roman and Littlefield.

Bachtler, J. Josserand, F., and Mitchie, R. (2003). EU Enlargement and the Reform of the Structural Funds: The Implications for Scotland. Stirling: Scottish Economic Policy Network.

Bogdanor, V. (1999). Devolution in the United Kingdom. Oxford: Oxford University Press. 
Brown, A., McCrone, D. and Paterson,L. (1996). Politics and Society in Scotland. Basingstoke: Macmillan.

Carrell, S. (2007, March 19). Nationalists' leader sets sights on historic prize. The Guardian. Retrieved March 19, 2007, from http://politics.guardian.co.uk/scotland/story/0,2037252,00.html

Dardanelli, P. (2001). The Europeanisation of the Centre-Periphery Paradigm: The Case of Scotland 1979-97. Paper presented to Workshop No. 4: Centres and Peripheries in a Changing World. Grenoble, France, 6-11 April 2001.

Denholm, A. (2004, April 16). EU President deals blow to SNP hopes. The Scotsman. Retrieved April 25, 2005, from http://thescotsman.scotsman.com/index.cfm?id $=428432004$

Finlay, R. J. (1993). Independent and Free: Scottish Politics and the Origin of the Scottish National Party, 1918-45. Edinburgh: John Donald.

Finlay, R. J. (1995). Continuity and Change: Scottish politics 1900-45. In T.M. Devine and R.J. Finlay (Eds.). Scotland in the Twentieth Century (pp.64-84). Edinburgh: Edinburgh University Press.

Gellner, E. (1983). Nations and Nationalism. Oxford: Basil Blackwell.

Guiberneau, M., and Rex,J. (ed.) (1997). The Ethnicity Reader, Cambridge:Polity.

Happold, M. (1999). Scotland Europa: Independence in Europe. London:Centre for European Reform.

Hix, S. (1999). The Political System of the European Union. Basingstoke: Macmillan.

Keating, M. (2003), European Integration and the Nationalities Question. S. Domenico di Fiesole, Italy:European University Institute.

Kikas,G.(1997, March). Scottish Nationalists and 'Europe'. Contemporary Review . Retrieved January 16, 2007, from Find Articles database http://findarticles.com/p/articles/mi_m2242/is_n1574_v270/ai_19420273

Kymlicka, W. (2001). Politics in the Vernacular: Nationalism, Multiculturalism and Citizenship. Oxford: Oxford University Press. 
Lynch, P. (1996). Minority Nationalism and European Integration. Cardiff: University of Wales Press

Lynch, P. (2002). SNP The History of the Scottish National Party . Cardiff: Welsh Academic Press.

Macdonell, H. (2007, January 8) Doubts over automatic EU entry for an Independent Scotland. The Scotsman. Retrieved January 20, 2007, from http://news.scotsman.com/scotland.cfm?id=35012007

Macdonell, H. (2007, January 16) Young Scots are strongest supporters of the Union. The Scotsman. Retrieved January 20, 2007, from $\mathrm{http} / /$ thescotsman.scotsman.com/index.cfm?id=77432007

Magnusson, M. (2001). Scotland The Story of A Nation. London: HarperCollins

McCrone, D. (2003). W(h)ither the Union? Anglo-Scottish relations in the 21 st Century. Lecture given at Symposium on Anglo-Scottish Relations since 1914, organized by the British Academy and the Royal Society of Edinburgh at the Royal Society of Edinburgh 6-7 November 2003.

Middleton, J. (2001) Political Influences. Retrieved January 12, 2007, from http://website.lineone.net/_joe_middleton/political.htm

Mitchell, J.(1996). Strategies for Self-government: The Campaigns for a Scottish Parliament 1996, Edinburgh: Polygon

Mitchell, J. (1996a). Scotland in the Union, 1945-95: The Changing Nature of the Union State. In T.M. Devine and R.J. Finlay (Eds.). Scotland in the Twentieth Century (pp. 85-102). Edinburgh: Edinburgh University Press.

Nairn, T.(1997). Faces of Nationalism. Janus Revisited. London: Verso

Paquin, S. (2002). Globalization, European Integration and the Rise of NeoNationalism in Scotland. Nationalism and Ethnic Politics, 8, (1), pp.5580.

Pittock, M. G.H., (2001). Scottish Nationality.Basingstoke: Palgrave.

Pittock, M. G.H, (2003). A New History of Scotland. Stroud: Sutton Publishing. 
Roessingh, M. A. (1997). Ethnonationalism and Political Systems in Europe - A State of Tension. Amsterdam: Amsterdam University Press.

Salmond, A. (1992). Scotland: A European Nation. Edinburgh: SNP.

Salmond, A. (2007, March 20) Only Scottish independence can solve the 'English Question'. Daily Telegraph. Retrieved March 20, 2007, from http://www.telegraph.co.uk/opinion/main.jhtml;jsessionid=DAID4LWY R2OCLQFIQMGCFGGAVCBQUIV0?xml=/opinion/2007/03/20/d12002 .xml

Scottish National Party, (1984). European Election Manifesto. Edinburgh: SNP.

Scottish National Party, (1992). Independence in Europe: Make It Happen Now-the 1992 Manifesto of the Scottish National Party. Edinburgh: SNP.

Scottish National Party, (1999). Scotland's Party, Scotland's Parliament: Manifesto for the 1999 Elections. Edinburgh: SNP.

Stavenhagen, R. (1990). The Ethnic Question: Conflicts, Development, and Human Rights. Tokyo: United Nations Press.

Swinney, J (2003, November 1). Speech to the Scottish Council of the European Movement, Perth. Retrieved July 4, 2004, from http://www.snp.org/index_800.php?pageName=home_content.php/speec hes_67(1).pdf

UK:Scotland Reid accused of 'empire building' (1999, October 22) BBC News. Retrieved January 4, 2007 from http://news.bbc.co.uk/2/hi/uk_news/scotland/480912.stm 